\section{Organization of Arab Petroleum Exporting Countries (OAPEC)}

Established in 1968 to promote co-operation and close ties between member states in economic activities related to the oil industry; to determine ways of safeguarding their legitimate interests, both individual and collective, in the oil industry; to unite their efforts so as to ensure the flow of oil to consumer markets on equitable and reasonable terms; and to create a favourable climate for the investment of capital and expertise in their petroleum industries.

Members. Algeria, Bahrain, Egypt, Iraq, Kuwait, Libya, Qatar, Saudi Arabia, Syria, Tunisia ${ }^{\star}$, United Arab Emirates. ${ }^{\star}$ Tunisia’s membership was made inactive in 1986.

Headquarters: PO Box 20501, Safat 13066, Kuwait.

Website: http://www.oapecorg.org

Email: oapec@oapecorg.org

Secretary-General: Abbas Ali Naqi (Kuwait).

\section{Organization of the Petroleum Exporting Countries (OPEC)}

Origin and Aims. Founded in Baghdad in 1960 by Iran, Iraq, Kuwait, Saudi Arabia and Venezuela. The principal aims are: to unify the petroleum policies of member countries and determine the best means for safeguarding their interests, individually and collectively; to devise ways and means of ensuring the stabilization of prices in international oil markets with a view to eliminating harmful and unnecessary fluctuations; and to secure a steady income for the producing countries, an efficient, economic and regular supply of petroleum to consuming nations, and a fair return on their capital to those investing in the petroleum industry. It is estimated that OPEC members possess $75 \%$ of the world's known reserves of crude petroleum, of which about twothirds are in the Middle East. OPEC countries account for about $43 \%$ of world oil production (55\% in the mid-1970s).

Members. (Feb. 2018) Algeria, Angola, Ecuador, Equatorial Guinea, Gabon, Iran, Iraq, Kuwait, Libya, Nigeria, Qatar, Saudi Arabia, United Arab Emirates and Venezuela. Membership applications may be made by any other country having substantial net exports of crude petroleum, which has fundamentally similar interests to those of member countries. Gabon became an associated member in 1973 and a full member in 1975, but in 1996 withdrew owing to difficulty in meeting its percentage contribution. However, it rejoined in July 2016. Ecuador joined the Organization in 1973 but left in 1992; it then rejoined in Oct. 2007. Indonesia joined in 1962 but left in 2008 as it had ceased to be an oil exporter; it then rejoined in Jan. 2016 despite being a net oil importer, only to leave again in Dec. of the same year.

Organization. The main organs are the Conference, the Board of Governors and the Secretariat. The Conference, which is the supreme authority meeting at least twice a year, consists of delegations from each member country, normally headed by the respective minister of oil, mines or energy. All decisions, other than those concerning procedural matters, must be adopted unanimously.

Headquarters: Helferstorferstrasse 17, A-1010 Vienna, Austria. Website: http://www.opec.org

Secretary-General: Mohammad Sanusi Barkindo (Nigeria).
Publications. Annual Statistical Bulletin._Annual Report._OPEC Bulletin (monthly).-Monthly Oil Market Report.-World Oil Outlook (annual).OPEC General Information. 2012.-OPEC Statute. 2012.

\section{Further Reading}

Parra, Francisco, Oil Politics: A Modern History of Petroleum. 2010

Yergin, Daniel, The Quest: Energy, Security and the Remaking of the Modern World. 2011

\section{OPEC Fund for International Development}

The OPEC Fund for International Development (OFID) was established in 1976 as the OPEC Special Fund, with the aim of providing financial aid on concessional terms to developing countries (other than OPEC member states) and international development agencies whose beneficiaries are developing countries. In 1980 the Fund was transformed into a permanent autonomous international agency and renamed the OPEC Fund for International Development. It is administered by a Ministerial Council and a Governing Board. Each member country is normally represented on the Council by its finance minister, or if not then by another designated person.

The initial endowment of the fund amounted to US\$800m. By the end of Sept. 2015 OFID's total approved commitments (including public sector operations, private sector operations, trade finance operations, grants and contributions to other institutions) stood at US $\$ 18,871 \mathrm{~m}$. OFID had approved 3,504 operations by 30 Sept. 2015, including US\$11,020m. for project financing, US\$724m. for balance-of-payments support, US\$333m. for programme funding and US $\$ 281 \mathrm{~m}$. for debt relief under the Highly Indebted Poor Countries Initiative. In addition, and through its private sector window, OFID had approved financing worth a total of US\$2,482m. in 229 operations in support of private sector entities in Africa, Asia, Latin America, the Caribbean and Europe. Through its grants programme OFID had also committed a total of US $\$ 613 \mathrm{~m}$. in support of a wide range of initiatives, ranging from technical assistance, research and emergency aid to dedicated operations to combat HIV/AIDS and hardship in Palestine.

Headquarters: Parkring 8, POB 995, A-1011 Vienna, Austria. Website: http://www.ofid.org

Email: info@ofid.org

Director-General: Suleiman Jasir al-Herbish (Saudi Arabia).

\section{Environmental Organizations}

\section{Friends of the Earth International}

Origin. Friends of the Earth was founded in 1971 by a network of environmental activists from France, Sweden, the UK and the USA.

Mission. The organization aims to 'collectively ensure environmental and social justice, human dignity, and respect for human rights and peoples' rights so as to ensure sustainable societies'.

Organization. Friends of the Earth International comprises 75 national member groups, with a combined membership of individuals exceeding $2 \mathrm{~m}$. around the world in some 5,000 local activist groups. A small, central Secretariat operates out of Amsterdam in the Netherlands and co-ordinates major campaigns, but grassroots activities are tailored by the relevant national or regional group.

Headquarters: Nieuwe Looiersstraat 31, 1017 VA Amsterdam,

Netherlands.

Website: http://www.foei.org

Chair: Karen Nansen (Uruguay). 